\title{
Determination of ochratoxin A in maize bread samples by LC with fluorescence detection
}

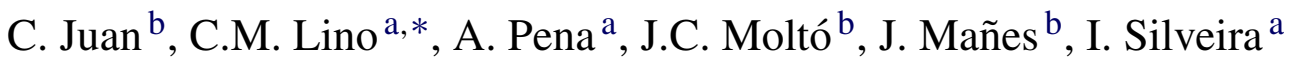 \\ ${ }^{a}$ Group of Bromatology, CEF, Faculty of Pharmacy, University of Coimbra, Rua do Norte s/n, 3000-295 Coimbra, Portugal \\ ${ }^{\mathrm{b}}$ Laboratory of Food Chemistry and Toxicology, Faculty of Pharmacy, University of Valencia, Av. Vicent Estellés s/n, 46100 Burjassot, Valencia, Spain
}

Received 4 January 2007; received in revised form 13 March 2007; accepted 15 March 2007

Available online 24 March 2007

\begin{abstract}
Ochratoxin A (OTA) is a secondary fungal metabolite produced by several moulds, mainly by Aspergillus ochraceus, A. carbonarius, A. niger and by Penicillium verrucosum. The present work shows the results of comparative studies using different procedures for the analysis of OTA in maize bread samples. The studied analytical methods involved extraction with different volumes of PBS/methanol, different extraction apparatus, and clean-up through immunoaffinity columns. The separation and identification were carried out by high-performance liquid chromatography with fluorescence detection. The optimized method for analysis of OTA in maize bread involved extraction with PBS:methanol (50:50), and clean-up with IAC column. The limit of quantification was $0.033 \mathrm{ng} \mathrm{g}^{-1}$. Recoveries ranged from $87 \%$ to $102 \%$ for fortifications at 2.000 and $0.500 \mathrm{ng} \mathrm{g}^{-1}$, respectively, within-day R.S.D. of $1.4 \%$ and $4.7 \%$. The proposed method was applied to 15 samples and the presence of OTA was found in nine samples at concentrations ranging from nd to $2.650 \mathrm{ng} \mathrm{g}^{-1}$.
\end{abstract}

(C) 2007 Elsevier B.V. All rights reserved.

Keywords: Ochratoxin A; Maize bread; LC

\section{Introduction}

OTA is mainly produced by some species of Aspergillus and Penicillium, particularly Aspergillus ochraceus, A. carbonarius, A. niger and Penicillium verrucosum. These moulds can easily contaminate foodstuffs, although the occurrence of OTA in foods may depend on climatic conditions [1].

Toxicity of OTA is well documented in many animal species, including human beings [2]. It is probably related to the Balkan endemic nephropathy (BEN), and the International Agency for Research on Cancer [3] has classified OTA as Group 2B, a possible human carcinogen. Exposure to OTA is worldwide, as known by its detection in human serum or urine of people from many countries [4].

OTA occurs predominantly in cereal grains, cereal products, cocoa, spices, oilseeds, coffee beans and legumes. However, cereal products are the major group of food commodities where the toxin is of greatest impact. The frequency of food contam-

\footnotetext{
* Corresponding author. Tel.: +351 239859994; fax: +351 239827126.

E-mail address: cmlino@ci.uc.pt (C.M. Lino).
}

ination with OTA represents an important source of daily OTA intake, with consequences to human health [5]. Consequently, the European Union Scientific Committee for Human Feeding deemed necessary to take prudential measures in order to reduce the degree of exposure to OTA to levels below $5 \mathrm{ng} / \mathrm{kg}$ body weight (b.w.)/day [6].

The bread is a product of daily consumption and highly demanded; thus several authors have indicated bread as one of the main sources of daily intake of OTA [7-9]. The presence of OTA in bread results from the contamination of wheat flour, and probably only partly is destroyed during the bread making process [10].

Maize bread is a traditional and special type of bread very appreciated in Portugal, and it is consumed mainly in the North and Central Zone of country. This bread is made with cereals such as maize (Zea mays) and wheat (Triticum aestivum), where the ochratoxigenic moulds $A$. ochraceus and $P$. verrucosum, respectively, grows.

In Portugal, the agricultural production primarily consists in $1,425,000$ tons of cereals such as rice (146,000 tons), maize (780,000 tons), wheat (300,000 tons) and barley (10,000 tons) [11]. According to the FAO, the consumption of cereal in 
Portugal was $1,335,000$ tons in 2002 , and according to IACA was 152,7000 tons. The human consumption increased in the following order: barley, maize, rice and wheat [12].

Few analytical methodologies for OTA determination in bread have been reported. González et al. [13] used pressurised liquid extraction with methanol, and liquid chromatography with fluorescence detection (LC-FD) for determination. Frequently for cereals and derivatives, the common extraction methodologies are based on the solubility of OTA in organic solvents. In this way it has been used liquid extraction with different solvents such as chloroform [14,15], methanol [1,16,17] or methanol with aqueous solution bicarbonate $[18,19]$, and acetonitrile/water mixture $[20,21]$. For the sample preparation and clean-up, immunoaffinity columns (IAC) $[19,20]$, ion exchange columns [21], matrix solid phase dispersion with $\mathrm{C}_{8}$ and $\mathrm{C}_{18}$ (MSPD) $[22,23]$, solid phase microextraction (SPME) $[24,25]$ and molecularly imprinted solid phase extraction (MISPE) [15] have been used. IAC clean-up is widely used, allowing lower limit of detection compared to MSPD clean-up with $\mathrm{C}_{18}$ and accurate and reproducible results $[23,26]$. For detection and quantification of OTA and mycotoxins in general, the methods are based on thinlayer chromatography (TLC), enzyme-linked immunosorbent assay (ELISA) [27], liquid chromatography with electrospray ionization tandem mass spectrometry (LC/ESI/MS/MS) [21] and mainly liquid chromatography with fluorescence detection (LC-FD) [19,20].

As far as we know, bread and maize bread, very much consumed in Portugal, have never been evaluated regarding OTA contamination. Furthermore, even for other countries only few papers reported OTA levels in wheat bread $[10,13]$.

The objective in the present study was to optimize a sensitive and accurate method for determination of OTA in the maize bread samples by LC-FD, and providing data on the occurrence of OTA in 15 maize samples consumed in the central zone of Portugal.

\section{Experimental}

\subsection{Apparatus}

A Moulinex blender $700 \mathrm{~W} \quad(230-240 \mathrm{~V}, \quad 50-60 \mathrm{~Hz})$ (Barcelona, Spain), a Braun MR $5000 \mathrm{M}$ multiquick/minipimer $500 \mathrm{~W}$ (220-230 V, 50-60 Hz, Esplugues del Llobregat, Spain), an Ultra-Turrax homogenizer Ystral Gmbh Drive X10/25 (230 V; 50/60 H, Dottingen, Germany), a vacuum manifold of Macherey-Nagel (USA), a pump of Dinko (mod. D-95, $130 \mathrm{~W}$, $220 \mathrm{~V}$ ), a centrifuge (Meditroni S-599, Selecta, Barcelona, Spain), a magnetic stirrer (Agimatic-S, Selecta, Barcelona, Spain), a Retsh vortex mixer (Haan, Germany), and a Sonorex RK 100 ultrasonic bath (Berlin, Germany) were used.

The LC apparatus used consisted of a pump (Model 307, Gilson Medical Electronics, Villiers-le-Bel, France), one $50 \mu \mathrm{L}$ Rheodyne injector (mod. 7125, Cotati, CA, USA), a guard column Hichrom Ltd., HI-173 (30 mm $\times 4 \mathrm{~mm}$ i.d.) (England), and a column Hichrom $\mathrm{C}_{18}(5 \mu \mathrm{m}, 250 \mathrm{~mm} \times 4.6 \mathrm{~mm}$ i.d.). A Perkin-Elmer spectrofluorimeter (Model LS 45, Perkin-Elmer, Beaconsfield, UK), operating at an excitation wavelength of
$333 \mathrm{~nm}$ and an emission wavelength of $460 \mathrm{~nm}$, was used. The spectral bandwidth was $10 \mathrm{~nm}$ for both excitation and emission. The mobile phase (acetonitrile/water/acetic acid 49.5:49.5:1.0, $\mathrm{v} / \mathrm{v} / \mathrm{v}$ ) was maintained at a flow rate of $1 \mathrm{~mL} / \mathrm{min}$.

The results were recorded on a 3390A integrator (HewlettPackard, Philadelphia, PA, USA).

\subsection{Chemicals}

Filter paper Whatman $\mathrm{N}^{\circ} 4(150 \mathrm{~mm} \emptyset$, Whatman International Ltd. Maidstone England) was used.

LC grade acetonitrile, methanol and toluene were purchased from Carlo Erba (Milan, Italy). Acetic acid, hydrochloride acid, sodium hydroxide, potassium chloride, potassium dihydrogenphosphate, anhydrous disodium hydrogenphosphate, and sodium chloride analytical grade were obtained from Merck (Darmstadt, Germany). Water was purified by distillation and passage through a Milli-Q system (Millipore, Bedford, MA, USA). OTA was purchased from Sigma Chemical Co. (St. Louis, MO, USA) with purity grade $\geq 98 \%$. Boron trifluoride-methanol (14\% solution) was obtained from Sigma Chemicals Co (St. Louis, USA).

A standard solution of OTA was prepared from the OTA vial purchased from Sigma. The standard stock solution was made in $4 \mathrm{~mL}$ toluene:acetic acid $(99: 1)$ at $250 \mu \mathrm{g} / \mathrm{mL}$, and stored at $-20^{\circ} \mathrm{C}$. An intermediate standard solution was prepared at $10 \mu \mathrm{g} / \mathrm{mL}$, by diluting $1 \mathrm{~mL}$ of stock standard solution with $25 \mathrm{~mL}$ toluene:acetic acid (99:1).

For fortification assays, a standard solution was prepared in toluene:acetic acid (99:1) at $1 \mu \mathrm{g} / \mathrm{mL}$ and two work solutions with mobile phase at 0.025 and $0.1 \mu \mathrm{g} / \mathrm{mL}$. For the calibration curve, standard solutions were prepared by evaporating $100 \mu \mathrm{L}$ of intermediate standard solution to dryness and diluting to $10 \mathrm{~mL}$ with mobile phase $(0.1 \mu \mathrm{g} / \mathrm{mL})$. After suitable dilutions in water:methanol:acetic acid (49.5:49.5:1), the working standard solution was used to prepare solutions at 10 and $5 \mathrm{ng} / \mathrm{mL}$, and $25 \mu \mathrm{L}$ were injected.

Phosphate buffer solution (PBS) was prepared from potassium chloride $(0.2 \mathrm{~g})$, potassium dihydrogen phosphate $(0.2 \mathrm{~g})$, anhydrous disodium hydrogen phosphate $(1.2 \mathrm{~g})$, and sodium chloride $(8 \mathrm{~g})$ added to distilled water $(900 \mathrm{~mL})$. After dissolution, the $\mathrm{pH}$ was adjusted to 7.4 (with $0.1 \mathrm{M} \mathrm{HCl}$ or $0.1 \mathrm{M} \mathrm{NaOH}$ as appropriate), and the solution was made to $1 \mathrm{~L}$.

IAC Ochratest columns (Vicam, Watertown, MA, USA) were used for clean-up.

All chromatographic solvents and water were degassed for 15 min in ultrasonic bath. Decontamination of the glassware was performed using a sodium hypochlorite solution. It was then acid-washed by immersing the glassware in a solution of $4 \mathrm{~mL} / \mathrm{L}$ $\mathrm{H}_{2} \mathrm{SO}_{4}$, and then washed to neutral $\mathrm{pH}$ by rinsing with distilled water.

\subsection{Sampling}

A total of 15 samples were purchased in commercially available size during September 2005 from bakeries, confectionery's shops and supermarkets located in the city of Coimbra and its 
countryside, central zone of Portugal. The samples were transported to the laboratory under ambient conditions. Samples were milled using a blender Moulinex.

All of the information about the samples was obtained from the labels. The milled samples were analysed as quickly as possible after the purchase. When this was not possible, they were stored at $-20^{\circ} \mathrm{C}$.

\subsection{Recoveries}

For recovery studies, $26.5 \mu \mathrm{L}$ of the OTA work solution prepared in mobile phase at $25 \mathrm{ng} / \mathrm{mL}$, and 50,100 and $400 \mu \mathrm{L}$ of the OTA work solution at $100 \mathrm{ng} / \mathrm{mL}$ were added to $20 \mathrm{~g}$ maize bread, and allowed to stand for $15 \mathrm{~min}$ at room temperature before extraction, for three replications. Because no certified reference materials for bread were available, trueness was assessed through recovery of additions of known amounts of OTA. The fortification levels were $0.033,0.25,0.50$ and $2.00 \mathrm{ng} / \mathrm{g}$, respectively (Tables 1-4).

Table 1

Mean recoveries and R.S.D.s obtained $(n=3)$ with different volumes of PBS/methanol (50:50) as extracting solvent using Minipimer apparatus

\begin{tabular}{llcc}
\hline $\begin{array}{l}\text { PBS:methanol } \\
\text { volumes }\end{array}$ & $\begin{array}{l}\text { Fortification } \\
\text { level }(\mathrm{ng} / \mathrm{g})\end{array}$ & Recovery $(\%)$ & R.S.D. $(\%)$ \\
\hline $50: 50(100 \mathrm{~mL})$ & 0.5 & 102.0 & 4.7 \\
$50: 50(75 \mathrm{~mL})$ & 0.5 & 65.0 & 17.8 \\
$50: 50(50 \mathrm{~mL})$ & 0.5 & 51.0 & 6.0 \\
\hline
\end{tabular}

Table 2

Mean recoveries and R.S.D.s obtained $(n=3)$ with different proportion of $\mathrm{PBS} / \mathrm{methanol}$ as extracting solvent

\begin{tabular}{llcl}
\hline $\begin{array}{l}\text { PBS:methanol } \\
\text { volumes }\end{array}$ & $\begin{array}{l}\text { Fortification } \\
\text { level }(\mathrm{ng} / \mathrm{g})\end{array}$ & Recovery $(\%)$ & R.S.D. (\%) \\
\hline 50:50 $(100 \mathrm{~mL})$ & 0.5 & 102.0 & 4.7 \\
$80: 20(100 \mathrm{~mL})$ & 0.5 & 99.6 & 0.7 \\
\hline
\end{tabular}

Table 3

Mean recoveries and R.S.D.s obtained $(n=3)$ between different agitation techniques using $100 \mathrm{~mL}$ PBS:MeOH (50:50) and OTA fortification level at $0.25 \mathrm{ng} / \mathrm{g}$

\begin{tabular}{lll}
\hline Agitation (time) & Recovery (\%) & R.S.D. (\%) \\
\hline Manual (15 min) & 50.0 & 6.0 \\
Ultra-Turrax (5 min) & 53.0 & 3.2 \\
Centrifugation (15 min) & 30.0 & 5.8 \\
Agitation plate (15 min) & 22.0 & 5.0 \\
\hline
\end{tabular}

Table 4

Accuracy and intra-assay validation results $(n=3)$ and inter-assay $(n=3)$ obtained with the optimized method

\begin{tabular}{lclc}
\hline $\begin{array}{l}\text { Fortification } \\
(\mathrm{ng} / \mathrm{g})\end{array}$ & $\begin{array}{l}\text { Recovery } \\
(\%)\end{array}$ & $\begin{array}{l}\text { R.S.D. } \\
\text { intraday }(\%)\end{array}$ & $\begin{array}{l}\text { R.S.D. } \\
\text { interday }(\%)\end{array}$ \\
\hline 0.033 & 80.4 & 8.8 & 12.1 \\
0.25 & 92.3 & 5.2 & 10.9 \\
0.5 & 102.0 & 4.7 & 11.4 \\
2.0 & 87.0 & 1.4 & 9.3 \\
\hline
\end{tabular}

\subsection{Sample extraction and clean-up}

An aliquot of sample $(20 \mathrm{~g})$ was extracted with $100 \mathrm{~mL}$ PBS/methanol (50:50, v/v) using the Braun Minipimer homogeniser for $5 \mathrm{~min}$; the mixture was filtered through a Whatman filter paper. After $20 \mathrm{~mL}$ aliquot of the filtered was diluted with $30 \mathrm{~mL}$ of PBS and then this solution was passed through an IAC column for clean-up using a vacuum manifold. The column was washed with $10 \mathrm{~mL}$ of water before eluting OTA with $3 \mathrm{~mL}$ of methanol. The methanol was dried at $\pm 50^{\circ} \mathrm{C}$ under a gentle nitrogen stream, and the residue was reconstituted in $250 \mu \mathrm{L}$ of mobile phase by mixing, and $50 \mu \mathrm{L}$ were injected in the LC system.

\subsection{Chemical confirmation of OTA by methyl ester formation}

For confirmation, OTA was converted into its methyl ester using boron trifluoride methanolic solution $14 \%\left(\mathrm{BF}_{3}-\mathrm{CH}_{3} \mathrm{OH}\right.$ $14 \%)[5,28]$. Sample extracts were evaporated to dryness, $150 \mu \mathrm{L}$ of the $\mathrm{BF}_{3}-\mathrm{CH}_{3} \mathrm{OH} 14 \%$ solution was added, and the mixture was left at $60^{\circ} \mathrm{C}$ for $10 \mathrm{~min}$. After evaporation, the residue was dissolved in $250 \mu \mathrm{L}$ of mobile phase.

\section{Results and discussion}

The calibration curves were obtained using the linear least squares regression procedure of the peak area versus the concentration. The linearity for OTA, in the working standard solutions at three determinations of five concentration levels, between 1 and $25 \mathrm{ng} / \mathrm{mL}$, was good as shown by the fact that the determination of the correlation coefficients $\left(r^{2}\right)$ are above 0.9990 for six calibration curves, prepared in three different days.

To optimize the extraction of OTA from maize bread, the extraction efficiencies were studied in order to achieve good analytical performance (Fig. 1). Firstly, OTA was extracted using the method of Pena et al. [28], previously used for rice samples. However, some modifications were needed. Three different volumes of PBS:methanol (50:50) were assayed as extracting solvent, using Minipimer apparatus: 50,75 and $100 \mathrm{~mL}$ by using $20 \mathrm{~g}$ of maize bread fortified with OTA at $0.5 \mathrm{ng} / \mathrm{g}$. The best recoveries were obtained with $100 \mathrm{~mL}$ of PBS:methanol (50:50) (Table 1). The extracting solvent was proved in different proportions and recoveries obtained with PBS:methanol (80:20) were slightly lower, $102 \%$ versus $99.6 \%$ (Table 2 ). This phenomenon may be due to the solubility power of methanol $[28,29]$. Higher percentage of methanol were not studied because OTA was able to could be elute from IAC columns [28], since methanol is one of the most potent desorbents [15].

Due to the characteristics of the sample, a more efficient process to separate the matrix residue from the solvent extract was essential. So, firstly filter paper Whatman $\mathrm{N}^{\circ} 4$ and secondly centrifugation at $3400 \times g$ for $15 \mathrm{~min}$, were evaluated, and it was observed that with the second approach the recovery was $30 \%$.

During the optimization of the method, different extraction procedures were assayed such as manual agitation, Ultra-Turrax, 

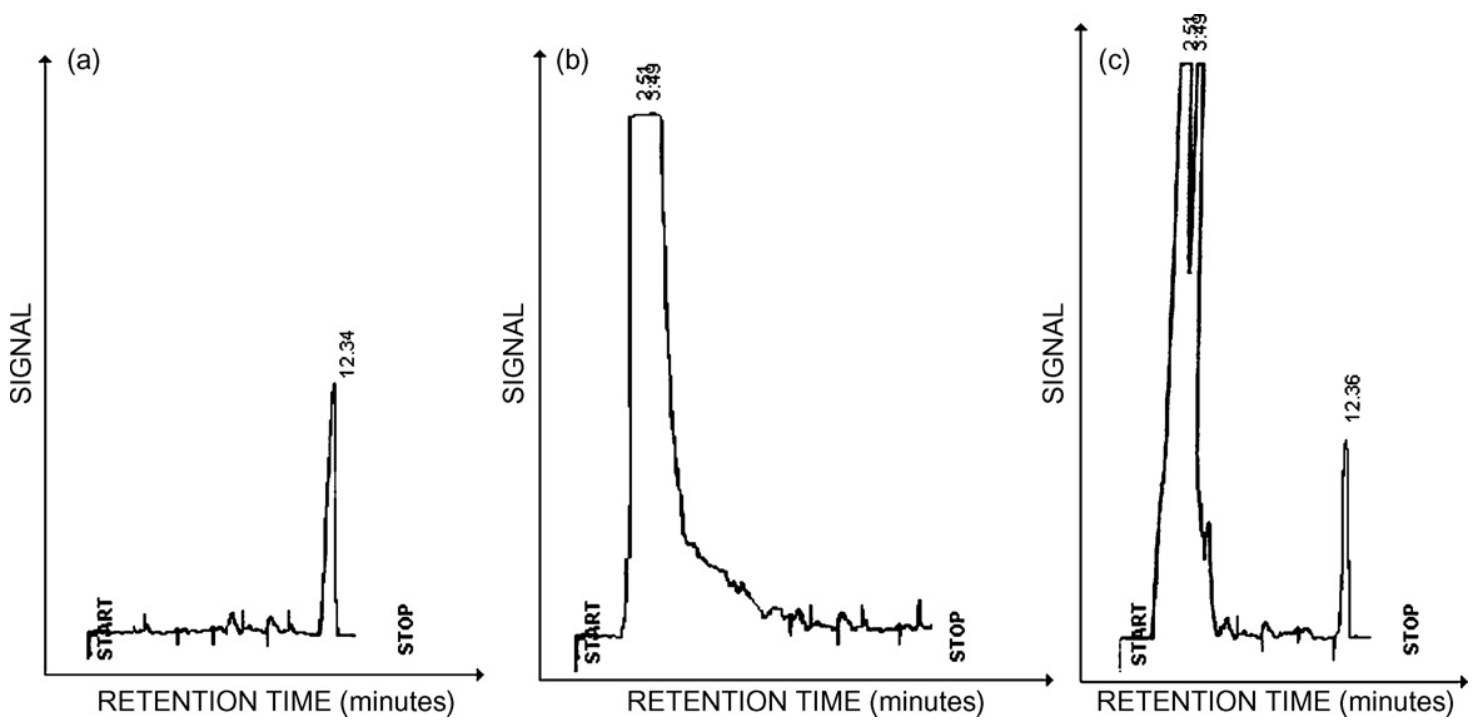

Fig. 1. LC-spectrofluorimeter chromatograms of: (a) solution of OTA standard at $10 \mathrm{ng} / \mathrm{mL}$; (b) a maize bread blank sample; and (c) a maize bread sample fortified with $0.5 \mathrm{ng} / \mathrm{g}$.

centrifugation and agitation plate. With these apparatus the recovery results oscillated between $22 \%$ and $53 \%$ (Table 3 ), which were overcome by Minipimer apparatus.

The accuracy for the optimized methodology was determined by calculating the mean recovery values used for each fortification level (Table 4). The recovery values oscillated between $102.0 \%$ and $80.4 \%$ for fortification levels at 0.5 and $0.033 \mathrm{ng} / \mathrm{g}$, respectively. The precision was calculated through intraday repeatability $(n=3)$ and interday repeatability (3 days). The intraday repeatability was between $8.8 \%$ and $1.4 \%$ for 0.033 and $2.0 \mathrm{ng} / \mathrm{g}$ fortification levels, respectively. The interday repeatability was between $12.1 \%$ and $9.3 \%$ for the same fortification levels.

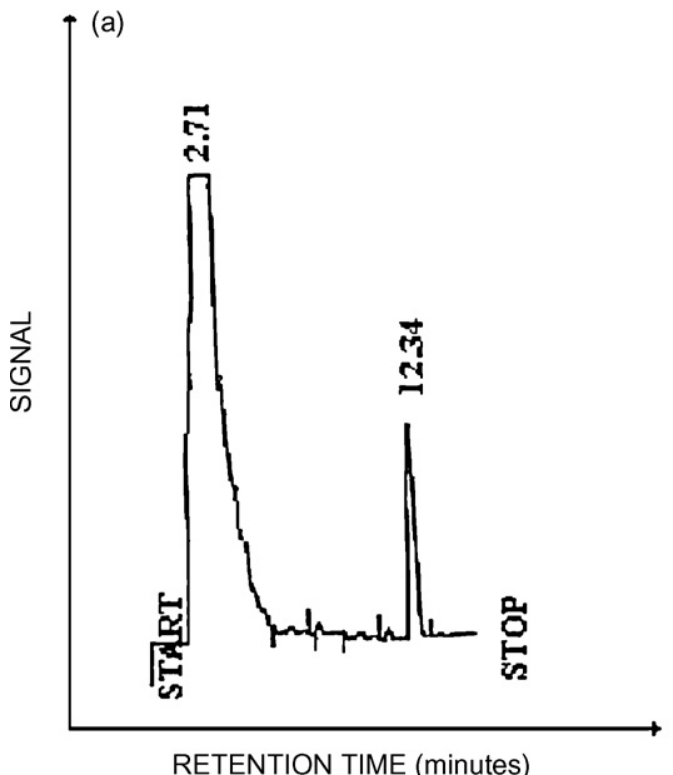

The LOQ was determined by the signal-to-noise approach, defined as that level resulting in a signal-to-noise ratio of approximately 10:1. The LOQ of the method was $0.033 \mathrm{ng} / \mathrm{g}$. This value is lower than the obtained by González et al. [13] using pressurized liquid extraction with methanol for the analysis of OTA in bread, $0.06 \mathrm{ng} / \mathrm{g}$.

\subsection{Application to real samples}

The optimized method of OTA extraction in maize bread followed by LC-FD was applied for the OTA analysis in 15 maize bread samples (Fig. 2). The frequency and incidence obtained are shown in Table 5. The frequency of OTA in analysed samples was

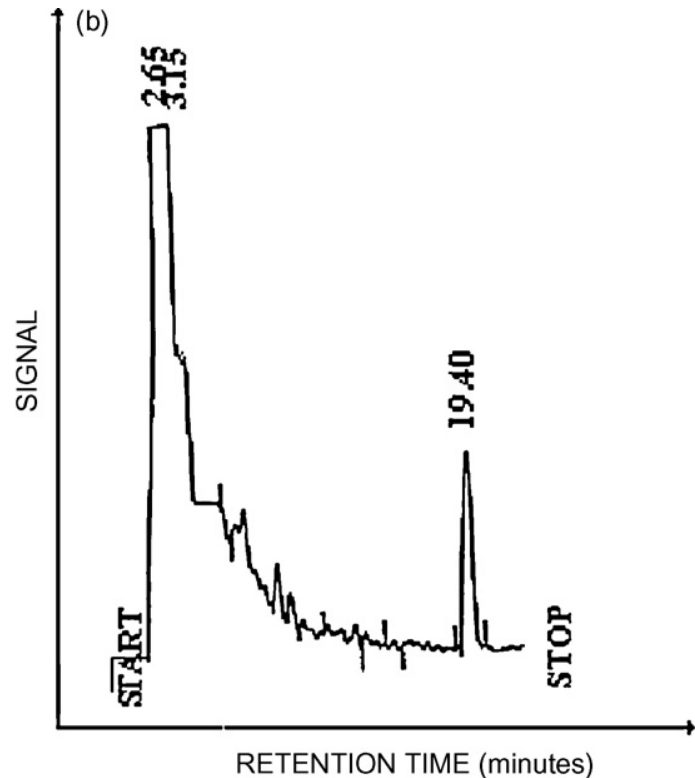

Fig. 2. LC-spectrofluometric chromatograms of: (a) a positive maize bread sample with $0.87 \mathrm{ng} / \mathrm{g}$ and (b) OTA methyl ester after boron fluoride-methanol derivatization. 
Table 5

Prevalence and levels of OTA in maize bread

No of analysed samples

No of positive samples

Frequency $(\%)$

$<$ LOQ

Range (ng/g)

Mean \pm S.D. $(n g / g)$

Median (ng/g)

$60 \%$ (nine positive samples). The OTA contaminated samples revealed levels ranging from 0.033 and $2.65 \mathrm{ng} / \mathrm{g}$ and were being the OTA mean level $0.43 \pm 0.9 \mathrm{ng} / \mathrm{g}$ and the median $0.08 \mathrm{ng} / \mathrm{g}$. Among the nine positive samples, one presented an OTA level of $2.65 \mathrm{ng} / \mathrm{g}$, which is near the maximum permitted level of OTA in cereal products established by the EU Commission Regulation, $3 \mathrm{ng} / \mathrm{g},[30]$.

Few studies about OTA levels in bread samples are available. González et al. [13] found two contaminated samples in 20 bread samples analysed in Spain with OTA levels of 2.55 and $1.82 \mathrm{ng} / \mathrm{g}$. Legarda and Burdaspal [10], in 255 samples of wheat bread from different countries, found $100 \%$ of incidence. The mean OTA levels ranged from $0.08 \mathrm{ng} / \mathrm{g}$ Austrian samples to $0.45 \mathrm{ng} / \mathrm{g}$ Spanish samples. The highest OTA level was found in one Spanish sample with $7.37 \mathrm{ng} / \mathrm{g}$.

In the contaminated samples, the presence of OTA was confirmed by methyl ester formation with boron trifluoride in methanol (14\%), followed by LC analysis. With this derivation the methyl ester was estimated to be $93 \%$ [28], therefore this reaction was not used for quantitative purposes.

\section{Conclusions}

Extraction with PBS/methanol, filtration and dilution with PBS allows the supernatant to be applied onto the IAC column, making it possible to achieve low limits of detection. This optimized analytical methodology provides good results in terms of accuracy, repeatability, intermediate precision and sensitivity, and has shown to be reliable for determination of OTA in maize bread, presenting limits of detection of $33 \mathrm{ng} \mathrm{kg}^{-1}$.

The application of the procedure to 15 samples from the central zone of Portugal has demonstrated that $60 \%$ were contaminated, although none of the samples exceeded the recommended limit.

\section{Acknowledgments}

This study was supported by the FCT, FEDER/POCTI, and CRUP (Integrated Action programme between Portugal and Spain, E-1/05 and HP04-69). The authors are gratefully acknowledged. C. Juan thanks the Spanish Ministry of Education and Science for the grant BI04-40.

\section{References}

[1] M. Arroyo, D. Aldred, N. Magan, Int. J. Food Microbiol. 98 (2005) 223-231.

[2] D. Hohler, Z. Ernahrungswiss 37 (1998) 2-12.

[3] IARC (International Agency for Research on Cancer). In "IARC Monographs on the Evaluation of Carcinogenic Risks to Humans: Some Naturally Occurring Substances; Food Items and Constituents, Heterocyclic Aromatic Amines and Mycotoxins" 56 (1993) 489 IARC (Ed). Geneve.

[4] A. Pena, M. Seirtová, C. Lino, I. Silveira, P. Solich, Food Chem. Toxicol. 44 (2006) 1449-1454.

[5] E. Moreno Guillamont, C.M. Lino, M.L. Baeta, A.S. Pena, I.N. Silveira, J. Mañes Vinuesa, Anal. Bioanal. Chem. 383 (2005) 570-575.

[6] EU (2002) Assessment of dietary intake of ochratoxin A by the population of EU member states (report for SCOOP task 3.2.7.) Available at http://europa.eu.int/comm/food/fs/scoop/index_en.html.

[7] B.C. Cholmakov, J. Wolff, M. Gareis, H. Bresch, P. Majerus, H. Rosner, R. Schneider, Archiv. füer Lebensmitterlhygiene 51 (2000) 111-115.

[8] M. Gareis, T. Scheuer, S. Ehrheardt, Mitteilungsblatt Derbundesanstalt füer Fleischforchung Kulmbach 39 (2000) 707-715.

[9] T.M. Legarda, P.A. Burdaspal, Alimentaria 321 (2001) 89-96.

[10] I. Subirade, Food Addit. Contam. 13 (1996) 25-26.

[11] FAO, Worldwide Regulations for Mycotoxins in Food and Feed in 2003 , vol. 81, FAO Food and Nutrition Paper, Rome, 2004.

[12] IACA, Associação Portuguesa dos Industriais de Alimentos Compostos para Animais. 2004. Available in http://www.iaca.pt/index.jsp?page= noticias\&id=74.

[13] L. González, J.M. Soriano, J.C. Moltó, J. Mañes, J. Chromatogr. A. 1113 (2006) 32-36.

[14] M.W. Trucksess, A.E. Pohland, Mycotoxin protocols, in: J.M. Walker (Ed.), Methods in Molecular Biology, vol. 157, Humana Press, New Jersey, 2001.

[15] S.N. Zhou, E.P.C. Lai, J.D. Miller, Anal. Bioanal. Chem. 378 (8) (2004) 1903-1906.

[16] S. De Saeger, L. Sibanda, A. Desmet, Int. J. Food Microbiol. 75 (2002) $135-142$.

[17] A.H.W. Abdulkadar, A. Al-Ali Abdulla, M. Al-Kildi Afrah, H. Jassim AlJedah, Food Control. 15 (2004) 543-548.

[18] J.W. Park, S.Y. Choi, H.J. Hwang, Y.B. Kim, Int. J. Food Microbiol. 103 (2005) 305-314.

[19] C. Araguas, E. Gonzalez-Penas, A.L. de Cerain, Food Chem. 92 (3) (2005) 459-464.

[20] D. Chan, S.J. MacDonald, V. Boughtflower, P. Brereton, J. Chromatogr. A 1059 (2004) 13-16.

[21] B. Delmulle, S. De Saeger, A. Adams, N. De Kimpe, C. Van Peteghem, Rapid Commun. Mass Spectrom. 20 (2006) 771-776.

[22] R. Biffi, M. Munari, L. Dioguardi, C. Ballabio, A. Cattaneo, C.L. Galli, P. Restani, Food Addit. Contam. 21 (6) (2004) 586-591.

[23] J. Blesa, H. Berrada, J.M. Soriano, J.C. Moltó, J. Mañes, J. Chromatogr. A 1046 (2004) 127-131.

[24] L. Monaci, F. Palmisanom, Anal. Bioanal. Chem. 378 (2004) 96-103.

[25] P.M.M. Scott, M.W. Trucksess, J. AOAC. Int. 80 (1997) 941-949.

[26] J. Gilbert, E. Anklam, Trends. Anal. Chem. 21 (2002) 468-471.

[27] T. Baydar, A.B. Egin, G. Girgin, S. Aydin, G. Sahin, Ann. Agric, Environ. Med. 12 (2005) 193-197.

[28] A. Pena, F. Cerejo, C. Lino, I. Silveira, Anal. Bioanal. Chem. 382 (2005) $1288-1293$

[29] K.A. Scudamore, M.T. Hetmanski, S. Nawaz, J. Naylor, Food Addit. Contam. 14 (1997) 175-178.

[30] European Commission 2005. Commission regulation (EC) No 123/2005 of 26 January 2005 amending regulation (EC) No 466/2001 as regards ochratoxin A. Official Journal of the European Union L25:3-5. 